\title{
The role of career exploration in career decision participants
}

\author{
Rio Hermawan ${ }^{*}{ }^{1}$, Muh Farozin ${ }^{2}$ \\ ${ }^{12}$ Universitas Negeri Yogyakarta \\ *) Corresponding author, $\equiv$ e-mail: riohermawan1990@gmail.com
}

\begin{abstract}
In the digital era, humans were required to be able to develop themselves suit with his/her potentials. Career selection was one of processes of making most important decision in an individual life. However, today the learners were facing various different career environment both in its characteristics as well as its kinds, and also there was a trend of learners less understand their potentials both due to their ignorance as well as due to undeveloped potentials owned. So that it gave a negative impact for selves in a career decision. So that understanding, awareness and acceptance towards potentials owned was very necessary in supporting career in the future. Efforts conducted in preparing learners' career were so many. The efforts in preparing it included through a career exploration. Roles of career exploration in a career decision related to career exploration area includes selection orientation, self exploration, environmental exploration, in-depth environmental exploration, decision status and commitment.
\end{abstract}

Keywords: career exploration; career decision,decision-making, career of learners.

How to Cite: Hermawan, R., \& Farozin, M. (2018). The role of career exploration in career decision participants. Couns-Edu: International Journal of Counseling and Education, 3(4): pp. 126-132. DOI: https://doi.org/10.23916/0020180315640

\section{Introduction}

In the digital age, people are required to be able to develop themselves in accordance with their potential and every individual must understand his abilities and be able to develop various other skills. With formal education being one part in helping learners to achieve career development tasks. This role Teacher guidance and counseling should be part in helping learners to achieve career development tasks. Because career development is an important component of the educational experience as it will involve work values, career exploration, employment choices and career decision making.

According to Suherman, U. (2008: 116) career exploration is the desire of individuals to search information on career information sources. Therefore exploration is very important to do early to help learners explore their careers. So career exploration will have an impact on someone's readiness to make career choices and decisions. Based on Taveira \& Moreno, (2003: 189-191). Career exploration is seen as an important part of career development, and is an important element in career decision making. In the process of career development, career exploration is needed for the readiness of a person to know and understand about the direction of interests and potentials that are expected so that the understanding then the individual can determine the job he wants and furthermore will make it easier to be able to focus on the field of careers in running it. Based on Suherman, U. (2008: 119) the tendency of problems often faced by learners in doing career exploration is usually less / not trying to dig and seek career information from 
various sources (Teacher Guidance and Counseling, successful parents, lack of insufficient knowledge of self-potential, including talent, interests, intelligence, personality, values and achievements, does not have enough career information.

Much research has been done regarding the contribution of career exploration in career decision making. Based on the research Arrington (2000: 103-109) explained that junior high school students have decision makers who have an effect on the future of education and their path. Learners will think about career plans. The foundation is career awareness and career exploration experience. This study shows that decision makers have an effect on the future of education and their paths and career exploration is very useful in providing experience for junior high school students. In addition, the exploration process is also very important to understand yourself and know about the career environment so that learners are able to make career decisions independently. Based on Bartley \&Robistschek's research, 2000: 63). In recent years, the level of individual career exploration has become an illustration of how one is able to determine career or vocational choice. Research conducted by Ferrari, L., Ginevra, M. C., Sara, S., Laura, N., Sgramella, T. M., \& Salvatore, S. (2015: 113-130). This study shows that career exploration can provide actual knowledge and perceptions of learners' career knowledge. Meanwhile, according to research Creed, P. A., Patton, W., \&Prideaux, L. A. (2006: 377-392). The results indicate an important role for self-efficacy and early work experience in career planning and exploration currently influencing career decisions and future high school students. According to Levi \& Ziegler's research. (1993: 10) Career exploration includes a range of activities including information gathering and knowledge on job searching, planning, opportunities, and career options. Based on Blair's research, 2012. Career exploration activities help students evaluate socialization and academic talent (Blair, 2012). In a study conducted by Gamboa, V., Paixao, M. P., \& De Jesus, S. N. (2013: 78). The results of this study found that the quality of work experience by using the relevant pre and post-internship is used to explore a career so that it can affect the development of vocational and career decision making students. In a study conducted by Gushue, G. V., Clarke, C. P., Pantzer, K. M., \&Scanlan, K. R. L. (2006: 307). The findings of this study indicate that the involvement of career exploration can determine career decision making and self-efficacy related to the identity of the department. Based on Hou's research, Zhi-Jin, \& Tracey, J. G. (2014: 654). The findings of this study indicate that the benefits of career exploration can predict career. Based on Wilkins research, $\mathrm{K}$. G., Santilli, S., Ferrari, L., Nota, L., Tracey, T. J.G., \&Soresi, S. (2014: 329). The findings of this study indicate that career exploration has two dimensions of career adaptability dimensions of curiosity and confidence. Based on Yanjun Guan's research, Fuxi Wang, Haiyang Liu, YuetingJi, Xiao Jia, Zheng Fang, Yumeng Li, HuijuanHua, \&Chendi Li. (2014: 95). The findings of this study indicate that parental support may affect career exploration. So support from parents is needed for continuity of career exploration. Based on research Vignoli, E. (2015: 182). The findings of this study indicate that the benefits of career exploration can address career anxiety and anxiety. Based on the research of Lee, B., Erik, J., Porfeli.,\&Hirschi, A. (2015). The findings of this study indicate that the benefits of career exploration can increase work valence and agency confidence.

The results of the above research it can be concluded that the role of career exploration in career decision making in learners is essential for information gathering and improvement of self-understanding and knowledge about the careers of learners. Career exploration aims to be able to describe the ability and competence of interest in want, as well as the process in the formation of interest in learners.

Therefore career is a part of life that affects the happiness of human life as a whole. Therefore the accuracy of choosing and determining career decision becomes an important point in the journey of human life. The decision to choose a career begins when the individual is in adolescence. In adolescence, schooling is an important aspect of life because education prepares them in a state of being ready to take a career selection and decision.

So that learners in making decisions require guidance from teachers, counselors, parents, or other adults so they can plan a future that matches their talents, interests, or abilities. An objective view of work helps learners develop and design a better and brilliant future.

Career selection is one of the most important decision-making processes in an individual's life. Teacher career decisions are influenced by internal and external factors. According to Sardiman (2007: 89- 
91), internal factors include the level of intelligence, mental attitude, gender, religion, talent, interest and future orientation. External factors include the economic level of the family, parents, teachers, friends and social conditions of the community. Based on Suherman, U. (2008: 120) problems in career decision making that often faced by adolescent student that is problem in making career decision which often faced by learners that is: lack / inadequate knowledge about making career decision, not knowing how to make career decisions, not knowing the steps in making career decisions, especially career plan preparation, lazy / unwilling to learn how other people make career decisions, do not have a good understanding of the strengths and weaknesses associated with career choices desirable, unable to see the factors that would support or hinder the desired career, not being able to see the opportunities that exist with regard to the desired career choice, not being able to choose one of the alternative occupations of diverse occupations; and can not develop learning habits and work effectively.

This article is intended to review the role of career exploration in career decision making learners. It reveals that the role of career exploration in schools has an important role in helping learners recognize and understand their careers, and be able to explore their careers, and plan for the future in accordance with the expected life form, so as to determine and make career decisions appropriately and responsible for his decision.

\section{Method}

This article uses an analytic descriptive type, which describes and analyzes how current learners and what efforts are made in career decisions. The types of data used in this article are secondary data obtained from literature, books, journals, reports and information from BK teachers in the field. Data collection techniques used are library studies (library research) by searching and collecting secondary data sourced from various references both books, journals, internet, learners, and teacher's BK which validity can be accounted for. The analysis technique used in this article is the method of content analysis that is by explaining and analyzing from existing sources, after which various references are associated with the research undertaken.

\section{Results and Discussions}

The Guidance and Counseling is a service activity that has the purpose of understanding, receiving, realizing, directing, making decisions and realizing decisions with responsibility. While career guidance is a service activity that aims to learners are able to recognize, understand and understand the world of work and understand the interests and talents in accordance with himself. According to Winkel and Sri Hastuti (2013: 632) describes the process of career development is divided into five stages, namely development phase $(<15)$, explorative phase (15-24), stability phase (25-44), coaching phase (45-65), and phase setbacks. This we need to observe that in the exploration phase learners are expected to explore all the potential they have. At this stage learners develop understanding and awareness of himself and the world of work and start trying new roles to be more prepared with his choice in the world of work. Another point is also explained by According to Greenhaus \& Callanan (2006: 103-107) explains that career exploration is one way or effort as a collection of information about the characteristics and knowledge of the environment, with the aim of fostering progress and self-development. Meanwhile, according to Bora Lee, Porfeli E. J, \& Hirschi. A. (2015: 152-134) Career exploration is a critical process for the development of children and youth that leads people to appropriate work and develops vocational identity. This shows that in adolescence is the beginning of learners explore their respective careers.

The purpose of career exploration according to Permedikbud (2014: 15) confirms that the aim of career guidance and counseling is to facilitate career development, exploration, aspirations and decisionmaking throughout the life span of learners / counselees. Thus the purpose of career exploration is to facilitate in understanding the self and the career environment of learners / counselees. In line with the regulation, Greenhaus and Callanan (2006: 104) explain that there are two types in career exploration. Self exploration and environmental exploration. Such self-exploration is the focus on excavating the value of a job, career interest, past experience, talents, acquiring a deep understanding of self and career goals. While 
the exploration of the environment in question is the exploration of positions, jobs, organizations and families. While based on Holland, in Brown, (2005: 24-25). Career exploration is an effort given by counseling teachers and counselors / counselors in their efforts to provide assistance and facilitate students / counselees so that they can use their personal and enviromental resources available to them, appropriate and congruent with their personalities. There are several opinions about the purpose of career exploration whereas according to Purwanta, E. (2012: 8-15) describes the purpose of career exploration in the guidance service is that students / counselees can: plan the completion of the study activities, career development and life in the future, developing all of the potentials of self, adjusting to the environment, and overcoming the obstacles faced during the study.

All of these goals lead to the experience and knowledge retention of learners. This means that learners can be said to be ready when he has had a lot of experience and have a broad understanding of both the world of work, colleagues and so forth. therefore, the career exploration phase of learners as peroses for career decision-making learners. There are various strategies that can be done in carrying out career exploration. The strategies are career fantasy, temporary apprenticeship, tour work, research career, career interview, interpersonuer project, career portfolio, self-assessment, self-discovery, integrated curriculum, career exploration package, parent class present, group dynamics, leadership training, problems, decision making, and communication skills (Studer, JR 2005: 185). While the Career Exploration Center at Cornell University states among others are; The first step, understand yourself and assess yourself. Knowing about yourself is the basis of career decision making. What are your interests, skills, values? What's important to you about your work? What are your personal traits and characteristics ?. The second step, gathering Information about career. Learn about careers, occupations, educational requirements, and job functions that are important in understanding careers that match your interests and goals. Third step: Integration. This step requires you to take what you know about yourself and put it together with the reality of the working world. You begin to evaluate career choices that are practical to you. With a variety of strategies that can be applied in carrying out career exploration, learners are expected to recognize himself and the world of work so that he is able to compete in the labor market. In addition, Learners will be more prepared in the career, confident and have a good self efficacy in facing the work environment and learners are able to make career decisions in accordance with the potential they have.

According to Gati, I., Asher. (2001: 331-341) career decision making is an individual process for seeking career information, sorting and comparing and up to a set of choices. Thus it can be stated that a career decision is an action to be able to decide or make choices on a career choice from various career options available. So that aspects of decision making become important things to be mastered in taking a decision. according to Germeijs, V., Verschueren, K., \& Soenens, B. (2006: 397-410) discloses six core aspects of the career decision-making process, with respect to further study: (1) the orientation of choice, ie awareness of the importance of making choice and motivation to engage in decision making, (2) self exploration, which is collecting information about oneself in this case including information of excess and lack of self, (3) environmental exploration, that is collecting general information about environment related to alternative study option (5) decision status, namely progress in choosing alternative career decisions, (6) commitment, ie belief in alternative career decision to be selected.

The basic factors that influence career decision making according to K. Mitchell \& Krumboltz (Patton, WA, \& McMahon, ML, 2014: 96) say there are four basic factors that affect career decision making ie each of the four components of this career decision plays an important role in the eventual selection of certain career alternatives, the four components of which are heredity, genetic, environmental conditions, learning experiences and task-setting skills. Meanwhile, according to Ming-Shang Su, Ta-Chun Chang, Chin-Chang Wu, \& Chin-Wen Liao. (2016: 843-850). Factors Affecting Student Career Decision Making are as follows: (1) the main factors affecting a student's career decision are "personal factors", (2) students studying in schools on a larger scale and taking home-based courses most vulnerable to the influence of "personal factors" in educational decisions, (3) for students with middle- and college-educated parents, "family factor" is the most influential student decision-making factor, (4) for students enrolled in home course, "school factor" is the most prominent factor in a student's career decision, (5) attending a home course will affect the career exploration factor, and is the most important factor in the student's career decision. 
From some of the above exposures it can be concluded that career decisions are a career-making process by individuals looking for career alternatives, reviewing career choices, and making choices in a career choice. In career decisions there are six core aspects of the career decision-making process: career orientation that will be choice, self exploration, environmental exploration, in-depth environmental exploration, status / confidence in dropping a career decision, and the need for a commitment when it has dropped a career decision. The factors that can influence a person's career decisions are: personal, talent, interest, values in society, social environment (parents, family and peers), career understanding, individual decision-making and career exploration factors the most important role in the career decisions of learners.

After reviewing the two studies above it can be concluded that career exploration has an important role in career decision making. Based on the opinion Greenhaus \& Callanan (2006: 104) explains that there are two types of career exploration, namely: self-exploration and environmental exploration. This is in line with the opinions of Germeijs, V., Verschueren, K., \& Soenens, B. (2006: 397-410) reveals six core aspects of the career decision-making process: elective orientation, self-exploration, environmental exploration, environment in depth, decision status, and commitment. Thus the role of career exploration in career decision making by Germeijs, V., Verschueren, K., \& Soenens, B. (2006: 397-410) reveals six core aspects of the career decision-making process, namely: (1) awareness of the importance of making choices and motivations to engage in decision-making, (2) self-exploration is focused on excavating the value of a job, career interests, experience, talents possessed, gaining a deep understanding of self and career goals as well as collecting information about yourself in this case including information of the advantages and lack of self. So that learners are able to identify self-understanding and be able to selfassess, identify skills, values, interests, and strengths to analyze the feasibility of career paths and employment opportunities. Hopefully with learners already exploring their own careers to know about oneself is the basis of career decision making. What are your interests, skills, values? what is important to you about your work? what are your personal characteristics and characteristics ?, (3) the exploration of the environment in question is the exploration of position, occupation, organization and family. So learners are able to identify career information gathering including career, cultural, mission, career specialization, and current issues. It is expected that learners have explored their own careers to collect information about their careers, learn about careers, occupations, educational requirements, and job functions that are important in understanding careers that are relevant to their interests and goals; (4) deepseated exploration of information gathering details of alternative career options, (5) decision status, namely progress in choosing alternative career decisions, (6) commitment, ie confidence in a predetermined career choice.

Career exploration in schools is the most important factor in the career decisions of learners, where learners are directed and given the understanding to know the world of work, to know the career environment, deep understanding of self, and career goals, especially if learners who do not want to think it is seriously possible to enter the certain field of positions and career decisions to be established. Therefore, the role of guidance and counseling teachers should be able to capture the relationship between the qualifications required in holding a position, further education, and in various aspects of the career environment in the work market. Career exploration aspects include self-exploration and environmental exploration. Self-exploration is a focus on excavating the value of a job, career interest, experience, talents, acquiring a deep understanding of self and career goals. While the exploration of the environment is the exploration of positions, jobs, organizations and families.

The importance of career exploration is a key component in the formation of career interest in learners. Career exploration is important because it selects goals and flows to achieve future goals so that learners can make career decisions appropriately according to their interests and talents. Everyone would want to succeed in his career, because if successful in the career will increase the self-esteem and more appreciated the community compared with people who do not have a good career and learners will increase and able to take decisions independently and after graduation can compete in the labor market.

The purpose of the career exploration role in the career decisions of learners, namely: (1) plan a goal completion of studies, career development and life in the future, (2) develop all potential and ability possessed optimally, (4) an effort to prepare the learners' career exploration in enhancing their selfunderstanding and the outside world in the learner, (5) assessing (6) gathering information about the 
career, (7) to facilitate in understanding the self and the career environment of learners / counselors, (8) with the understanding of career exploration, learners are able to compete in the labor market.

\section{Conclusions}

In this matter, a guidance and counseling teacher should be a part in helping learners to achieve career development tasks. Due to career development became an important component from education experience because it will involve work values, career exploration, work selection and career decision making. Therefore this article considered the importance of career exploration roles in a right career decision taking and suitable with interest and talent of learners. One of efforts of career exploration role in learners career decision making, includes: (1) selection orientation, includes an awareness of the importance of making selection and motivation to get involve in decision making, (2) self exploration meant was focus on exploration of job values, career interest, previous experience, talent owned, acquire an in-depth understanding on self and career purpose and also gathering information on self in this case includes information of self advantages and disadvantages so that learners are able to identify self understanding and able tom assess self, identify skills, values, interest and power to analyse feasibility of career path and work opportunity. It was expected that learners already explored their own careers are be able to identify on self that was a principle in a career decision taking. What were your interest, skills, values? What important for you on your careers? What are your personal characteristics?, (3) environmental exploration meant were explorations of position, occupation, organization and family so that learners are able to identify information gathering on career covers career kinds, culture, mission, specialized field in career field and problems facing today. It was expected that learners have explored their own careers are able to gather information on career, learning about career, work kinds, educational requirements and important work function in understanding career suitable with interest and purpose, (4) in-depth environmental exploration includes gathering detailed information on career selection alternatives, (5) decision status includes advancement in selecting career decision alternatives, (6) commitment includes belief in career selection determined. The six facts would make learners were more convince and believe in ability and interest owned so that the learners are able to make decision on their careers and able to compete in work market.

\section{References}

Arrington, K. (2000). Middle Grades Career Planning Program. Journal Of Career Development. Volume 27. (2): 103-109.

Bartley, D. F. \& Robistschek, C. (2000). Career Exploration: A Multivariate Analysis of Predictors. Journal of Vocational Behavior. 56, 63-81.

Blair, J. E., et.al (2012). The Impact of Career Exploration upon the Success of Underrepresented Student in Higher Education.(Disertasi, Capella University, 2012).ProQuest LLC, 17, 112.

Brown, S. D., \& Lent, R. W. (2005). Career Development and Counseling; Putting Theory and Research to Work. Hoboken, New Jersey: John Wiley and Sons.

Cornell University. Retrieved September 25, 2017, from Auburn University and University of South Florida website: http://www.human.cornell.edu/

Creed, P. A., Patton, W., \& Prideaux, L. A. (2006). Predicting change over time in career planning and career exploration for high school students. Journal of Adolescence. Vol. 30 (2007) 377-392.

Ferrari, L., Ginevra, M. C., Sara, S., Laura, N., Sgramella, T. M., \& Salvatore, S. (2015). Career Exploration and Occupational Knowledge In Italian Children. International Journal for Education and Vacational Guidance. Vol.15, 113-130.

Gamboa, V., Paixao, M. P., \& De Jesus, S. N. (2013). Internship Quality Predict Career Exsploration of High School Student. Journal of Vocational Behavior. Vol.83,78-87.

Gati, I., Asher. (2001). High School Student Career-Realated Dicision Making Difficults. Jurnal Of Counseling and Development Vol. 79,331-341. 
Germeijs, V., Verschueren, K., \& Soenens, B. (2006). Indeciveness and High School Students Career Decision-Making Process: Longitudinal Associations and The Mediational Role of Anxiety. Journal of Counseling Psychology Vol. 53 No. 4. H1m. 397-410.

Greenhaus, \& Callanan. (2006). Encyclopedia Career Development. London: Sage.

Gushue, G. V., Clarke, C. P., Pantzer, K. M., \& Scanlan, K. R. L. (2006). Self Eficacy, Perceptions of Barries, Vocational Identity, and The Career Exsploration Behavior Of Latino/A High School Students. Career Development Wuartely. Vol. 54, 307-317.

Hou, Zhi-Jin, \& Tracey, J. G. (2014). Relation Of Enviromental And Self Career Exploration Decision Making Difficulties In Chinese Student. Journal of career assesment. Vol. 22 (4), 654-665.

Hurlock, E. B. (2012). Developmental Psychology (V Edition). Jakarta: Erlangga Publisher.

Lee B, Porfeli E. J, \& Hirschi. A. (2015). Between- and within-person level motivational precursors associated with career exploration. Journal of Vocational Behavior. Vol. 92 (2016) 125-134.

Lee, B., Erik, J., Porfeli., \&Hirschi, A. (2015). Between- and within-person level motivational precursors associated with career exploration. Journal of Vocational Behavior. Vol. 92 (2016), 125-134.

Levi, M., \& Ziegler, S. (1993). The role of career exploration as a component of an effective guidance program in the transition.British Journal of Guidance \& Counseling. 8, 6-15.

Mendikbud (2014). Education and Culture Regulation 2014111 About Guidance and Counseling In Basic Education and Secondary Education.Mendikbud (2014). Education and Culture Regulation 2014111 About Guidance and Counseling In Basic Education and Secondary Education.

Mendikbud (2014). Peraturan Pendidikan dan Kebudayaan Tahun 2014 No. 111 Tentang Bimbingan dan Konseling Pada Pendidikan Dasar dan Pendidikan Menengah.

Ming-Shang Su, Ta-Chun Chang, Chin- Chang Wu, \& Chin-Wen Liao. (2016). Factors Affecting the Student Career Decision-Making of Junior High School Students in Central Taiwan Area. International Journal of Information and Education Technology. Vol. 6, No. 11.

Patton, W. A., \& McMahon, M. L. (2014). Career Development and Systems Theory: Connecting Theory and Practice ( $3^{\wedge}$ nd Edition). The Netherland, Rotterdam: Sense Publishers.

Purwanta, E. (2012). The Role of Emotional Intelligence And Child Care Exploration Sltp. Journal of Psychopedagogia, Vol. 1, No. 1

Sardiman. (2007). Interaction and Teaching Motivation Motivation. Jakarta: PT. Raja Grafindo Persada.

Suherman, U. (2008). Career Counseling Throughout the Life Range. Bandung: Pascasarjana Universitas Pendidikan Indonesia Press.

Taveira, M. D., \& Moreno, M. L. R. (2003). Guidance Theory and Practice: The Status of Career Exploration. British Journal of Guidance \& Counseling.Vol. 31 no 2.Pp.189-208.

Vignoli, E. (2015). Career indecision and career exploration among older French adolescents: The specific role of general trait anxiety and future school and career anxiety. Journal of Vocational Behavior. Vol. 89 (2015), 182-191.

Wilkins, K. G., Santilli, S., Ferrari, L., Nota, L., Tracey, T. J.G., \&Soresi, S. (2014). The relationship among positive emotional dispositions, career adaptability, and satisfaction in Italian high school students. Journal of Vocational Behavior. Vol. 85 (2014), 329-338.

Winkel, W. S., \& Hastuti, M. S. (2013). Guidance and Counseling in Educational Institutions. Yogyakarta: The Eternal Media.

Yanjun Guan, Fuxi Wang, Haiyang Liu, Yueting Ji, Xiao Jia, Zheng Fang, Yumeng Li, Huijuan Hua, \& Chendi Li. (2014). Career-specific parental behaviors, career exploration andcareer adaptability: A three-wave investigation among Chineseundergraduates. Journal of Vocational Behavior. Vol. 86 (2015), 95-103 